\title{
ACTIVITÉ THYRoÏDIENNE DES PORCS « LARGE WHITE » ET « PIÉTRAIN »
}

\author{
G. MONIN et J. CHARPENTIER \\ Station de Recherches sur la Viande, \\ Centre de Recherches de Clermont-Ferrand, 63-Saint-Genès-Champanelle \\ Institut national de la Recherche agronomique
}

\section{RÉSUMÉ}

Le but de cette expérience était de préciser l'importance de l'hypothyroïdie dans l'étiologie de la myopathie exsudative et dépigmentaire du Porc. L'état fonctionnel de la thyroüde a été apprécié par l'étude de l'évolution de la radioactivité de la glande pendant une quinzaine de jours après l'injection d'iode radioactif et par divers tests histophysiologiques. Nos résultats montrent que la fixation thyroïdienne chez la race Piétrain, fréquemment sujette à la myopathie, est très inférieure à celle que l'on observe chez la race Large White. Il semble d'autre part que l'affaiblissement de la fixation thyroïdienne aille de pair avec une dégradation des qualités de la viande en particulier une diminution du pouvoir de rétention d'eau.

\section{SUMMARY}

THYROID ACTIVITY IN “ LARGE WHITE " AND " PIETRAIN " PIGS

The aim of this experiment was to define more accurately the importance of the hyperthyroidism in the etiology of the exudative and depigmentary myopathy in the pig. The functional state of the thyroid gland was estimated by studying the development of the radioactivity in the gland during two weeks after injection of radioactive iode and by different histophysiological tests. Our results show that in the Piétrain breed, often suffering from myopathy, the thyroid up take is much lower than that observed in the Large White breed. Moreover, it seems that the decrease of the thyroid uptake is on a part with a deterioration of the meat quality, in particular a decrease of the water binding effect. 